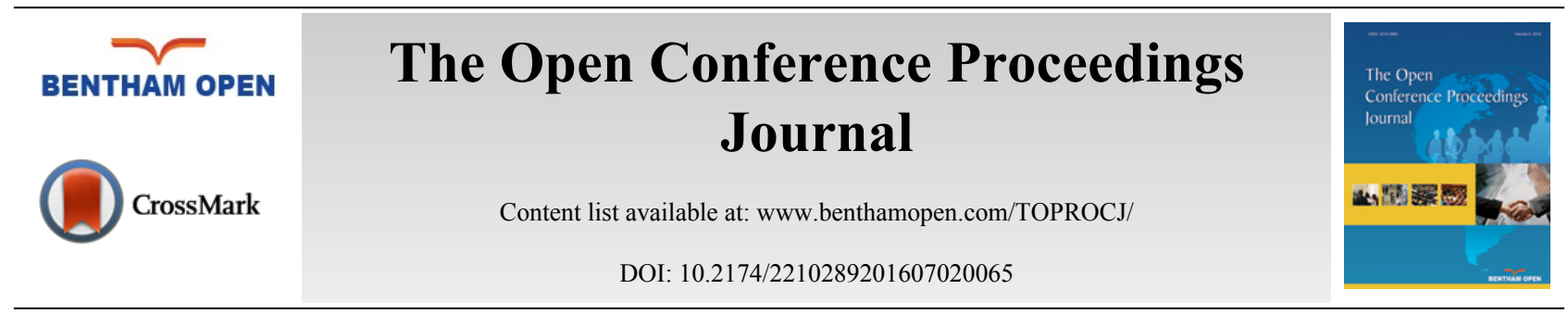

\title{
Biocleaning of Cultural Heritage Surfaces
}

\author{
Francesca Cappitelli \\ Dipartimento di Scienze per gli Alimenti, la Nutrizione e l'Ambiente, Università degli Studi di Milano, Milano, Italy
}

\begin{abstract}
Microbial agents are among the major causes of deterioration of cultural heritage, strongly affecting our global cultural legacy, the stone, glass, wood and other sources used to fabricate millions of artworks and monuments around the world. However, it is not all about rotting and erosion! Microbial action has been harnessed to clean the surfaces of stone sculptures and buildings and frescoes. In particular, the ability and potential of different microorganisms to remove undesired sulphates, nitrates and organic matter have been demonstrated a number of times in the last decade.
\end{abstract}

Keywords: Biocleaning, frescoes, nitrates, organic matter, stone, sulphates.

\section{INTRODUCTION}

Microorganisms are generally associated with detrimental effects on artistic materials [1, 2]. Yet if we look at nature, microbial communities are responsible for numerous positive processes and can provide 'services' to human beings. Microorganisms play important roles in biogeochemical cycles and in the food industry. For example, baked goods and alcoholic beverages rely on the fermentative activities of yeasts, which generate carbon dioxide to raise the dough and alcohol as key ingredients, respectively. Additionally, microorganisms can be used to clear out pollution (spilled oil, solvents, pesticides and other environmentally toxic compounds) in a process called bioremediation. Consequently, in the early 1990s, some microbiologists started to use them for the removal of harmful compounds such as sulphates on cultural heritage objects.

\section{SULPHATES}

Gauri et al. [3] were pioneers in exploiting the biocleaning potential of cultural heritage, using the sulphate reducing bacterium Desulfovibrio desulfuricans for the removal of black crusts from an old gypsum encrusted marble statue previously consolidated. The underlying idea was that biocleaning of altered surfaces could have some advantages over traditional cleaning methods as chemicals are not always selective and mechanical treatments can sometimes damage the surface. In addition, in the biological method, microorganisms act in the same way as they do in their natural environments. This preliminary experiment was successful but had two drawbacks: the treatment necessitated both the immersion of the object in a liquid medium and therefore was not suitable for large objects, and the consolidation of the statue prior to the treatment. Additionally, the removal of gypsum was assessed only by visual observation.

As an improvement over the previous method, some years later, Ranalli et al. [4] employed D. desulfuricans and D. vulgaris on two objects, i.e., an old marble "horse hoof" and an old marble column. The authors avoided immersion by using the inorganic material sepiolite as a delivery system for the bacteria. The limitation of method was the many days (10 to 14) required for the colonisation of the sepiolite.

Later on, Cappitelli et al. [5] proposed to entrap D. vulgaris cells in the poultice carrier Carbogel. Indeed, Carbogel proved to be superior to both sepiolite and Hydrobiogel-97 delivery systems, as it allowed an easy application of the

\footnotetext{
* Address correspondence to this author at the Dipartimento di Scienze per gli Alimenti, la Nutrizione e l'Ambiente, Università degli Studi di Milano, Milano, Italy; Tel: +39 02 50319121; Fax: +39 02 50319238; Email: francesca.cappitelli@unimi.it
} 
bacteria, maintaining the bioformulate in a state where microbial activity was feasible, and only three applications (for a total of $45 \mathrm{~h}$ ) were needed. Ion-exchange chromatography analysis showed that bacteria entrapped in the Carbogel matrix allowed removal of $98 \%$ of sulphates from the marble, while Carbogel alone removed only a small percentage of the undesired salts.

Biocleaning has been proved successful on many lithotypes, including limestone [6], even in the presence of heavy metals [7].

Comparing a chemical cleaning method, which involved an ammonium carbonate-EDTA mixture, and biocleaning involving $D$. vulgaris, for the removal of black crust from the marble of the Milan Cathedral (Italy), the biological procedure resulted in a more homogeneous removal of the surface deposits and preserved the patina noble under the black crust [8]. More recently, a study has evaluated the most appropriate cleaning treatment for black crust removal, adopting chemical (ammonium carbonate poultice), laser (1064 nm, Nd:YAG laser), and microbial cleaning for the removal of black crusts on colored artistic lithotypes of the Cathedral of Florence [9]. The effects of the different procedures on the original surfaces were evaluated by scanning electron microscopy coupled with energy dispersive X-ray spectroscopy, Fourier transform infrared spectroscopy and color measurements. One year later, further color measurements were made. It was found that chemical cleaning led to non homogeneous crust removal and that for the extremely powdery and incoherent red marlstone, the preferred treatment was laser cleaning. Overall, regarding this specific case-study the most satisfactory treatment was the microbial cleaning process which proved to be the most controllable and efficient process for sulphate removal. Its main drawback appeared to be the time needed to remove thick black crusts since numerous applications were necessary (up to four poultice applications (each of $10 \mathrm{~h}$ )).

To address time challenge, the effects of a sulphate reducing bacterium strain coupled with a non ionic detergent pre treatment were studied on a century old artistic marble affected by black crusts [10]. Compared to the biocleaning alone, the co-treatment needed fewer biological applications and resulted in a $70 \%$ reduction in total cleaning time, still retaining all the advantages of the biocleaning approach.

\section{NITRATES}

The bioremoval of nitrate salts was performed from the tuff stone surfaces of the $12^{\text {th }}$ century Matera Cathedral, which had been altered by nitrates, using nitrate reducing bacteria. In order to establish the impact of the biocleaning on the treated surfaces, color variation, mineralogical and chemical analyses were carried out to evaluate the nitrate removal and to monitor the long term effects on the surface. Nitrate removal was successful and six years later, in the areas that had been treated using bacteria, the nitrate concentration remained stable; no noteworthy presence of microflora or color change were measured in comparison with an untreated control area [11].

Eighteen century wall paintings of the Santos Juanes church in Valencia, Spain, presented insoluble nitrate salt efflorescences as they had been severely damaged during the Spanish Civil War and poorly restored twenty five years later. As physical and chemical treatments (such as ion exchange resins) did not yield the desired cleaning results, the paintings were cleaned using Pseudomonas stutzeri with a reduction of $92 \%$ in nitrates assessed by ion chromatography [12]. In this study, the agar agar delivery system proved to be the most appropriate choice as it showed good adhesive properties when applied onto vertical surfaces and produced homogeneous cleaning without stains or any kind of residue left on the cleaned surface.

\section{ORGANIC MATTER}

The process of detaching frescoes from walls prior to restoration calls for notable quantities of organic compounds (such as glue and casein) that are distributed on both the painted surface and at the back of the fresco. If not carefully removed, organic matter can pose serious danger to the preservation of the artwork itself. This was the case of the XIV century fresco Conversione di S. Efisio e battaglia, painted by Spinello Aretino, held at the Monumental Cemetery of Pisa. The painting suffered the worst damage in 1944, when American soldiers bombed the cemetery and the wooden roof caught fire. The fresco was detached from the wall by conservators who, during the conservation treatment, had also mixed a biocide to the glue [13]. This biocide prevented the growth of microorganisms but unfortunately, over time, has favoured polymerisation posing difficulty in removing such organic compounds by traditional methods. In this case study, a strain of P. stutzeri was selected because these bacteria are known to use a wide variety of organic compounds for their metabolism, and are specifically able to attack the aged undesired organic matter. Bacteria were excellent biorestoration agents on the fresco [14]. 
Mazzoni et al. [15] employed microorganisms for the removal of deposits composed of gypsum, calcium oxalate dihydrate (weddellite), calcium carbonate, apatite and a protein compound, probably aged casein, from the wall paintings of the lower loggia of the Casina Farnese (Palatine Hill, Rome). The presence of calcium carbonate was attributed to the carbonate nature of the plaster on which the paintings were executed; gypsum to the plaster sulphatation processes or as a result of capillary infiltration of the walls; and calcium oxalate to the degradation of a superficially applied compound. Stenotrophomonas maltophilia was used for the removal of organic deposits; P. koreensis for the removal of phosphate and organic deposits; and Cellulosimicrobium cellulans for the solubilisation of carbonate and gypsum deposits. Interestingly, Mazzoni et al. [15] noted that bioprecipitation of calcium carbonate has been applied several times with the aim of consolidating ornamental surfaces [16], while studies aimed specifically at identifying microbial species able to solubilise carbonates are still rare. Additionally, a new support matrix, Laponite, was employed as it was found both appropriate for conservation purposes and compatible with the microorganisms. An important advantage of using the selected strains was that due to the difficulty of thermally insulating the loggia, the applications were carried out at temperatures ranging between $6^{\circ} \mathrm{C}$ and $37^{\circ} \mathrm{C}$. Despite this, no decrease in the efficiency of the cleaning treatment was reported.

Paints produced in the $20^{\text {th }}$ and $21^{\text {st }}$ centuries, including spray paints used for graffiti, often contain synthetic polymers. Current methods for the removal of graffiti include chemical and physical (including laser) approaches. Bioremediation has a great potential as a novel approach to graffiti removal [17]. Microorganisms have been proposed for the removal of synthetic polymers used as conservation materials and in paints from cultural heritage surfaces, e.g. nitrocellulose [18]. So far, only one published study has focused on bioremediation of graffiti spray paint, proposing a strain of $D$. desulfuricans as a good candidate for the degradation of nitrocellulose [19].

\section{CONCLUSION}

In order to introduce a ready to use biocleaning product to the conservation market, two basic aspects must be taken into account: the microorganism itself and the delivery system to be used [20]. Some microorganisms used for biocleaning are available on the market, e.g. those sold by the company Micro4you, Italy [21]. At present, the delivery system is generally chosen by conservators according to their experience. Nevertheless, as the delivery system is one of the most important aspects of biocleaning technology, Bosch-Roig et al. (2014) suggested to take into account some carrier features before using them: i) the ability to provide the microorganisms with the right conditions (e.g. water); ii) easy applicability to all types of surfaces whatever the orientation; iii) easy preparation and application, and also convenient elimination at the end of the treatment.

Biocleaning had been proposed as the traditional chemical or physics based cleaning methods were not entirely satisfactory, with the latter displaying many drawbacks including health problems caused to conservators and the risk of further damaging the object. In contrast, biocleaning offers many advantages including selectivity, no effects on the health of conservators, no pollution, relatively low cost, high homogeneity of the deposits removal, and absence of ethical implications [22, 23].

In conclusion, being a sustainable approach, biocleaning is a way to go green in conservation practice.

\section{CONFLICT OF INTEREST}

The author confirms that this article content has no conflict of interest.

\section{ACKNOWLEDGEMENTS}

Declared none.

\section{REFERENCES}

[1] Cappitelli, F.; Abbruscato, P.; Foladori, P.; Zanardini, E.; Ranalli, G.; Principi, P.; Villa, F.; Polo, A.; Sorlini, C. Detection and elimination of cyanobacteria from frescoes: the case of the St. Brizio Chapel (Orvieto Cathedral, Italy). Microb. Ecol., 2009, 57(4), 633-639. [http://dx.doi.org/10.1007/s00248-008-9441-4] [PMID: 18752018]

[2] Cappitelli, F.; Salvadori, O.; Albanese, D.; Villa, F.; Sorlini, C. Cyanobacteria cause black staining of the National Museum of the American Indian Building, Washington, DC, USA. Biofouling, 2012, 28(3), 257-266.

[http://dx.doi.org/10.1080/08927014.2012.671304] [PMID: 22435895] 
[3] Gauri, K.L.; Parks, L.; Jayne, S.J.; Atlas, R. Removal of sulfated crusts from marble using sulfate reducing bacteria. 1992.

[4] Ranalli, G.; Chiavarini, M.; Guidetti, V. The use of microorganisms for the removal of sulphates on artistic stoneworks. Int. Biodeterior. Biodegradredation, 1997, 40, 255-261. [http://dx.doi.org/10.1016/S0964-8305(97)00054-1]

[5] Cappitelli, F.; Zanardini, E.; Ranalli, G.; Mello, E.; Daffonchio, D.; Sorlini, C. Improved methodology for bioremoval of black crusts on historical stone artworks by use of sulfate-reducing bacteria. Appl. Environ. Microbiol., 2006, 72(5), 3733-3737. [http://dx.doi.org/10.1128/AEM.72.5.3733-3737.2006] [PMID: 16672524]

[6] Polo, A.; Cappitelli, F.; Brusetti, L.; Principi, P.; Villa, F.; Giacomucci, L.; Ranalli, G.; Sorlini, C. Feasibility of removing surface deposits on stone using biological and chemical remediation methods. Microb. Ecol., 2010, 60(1), 1-14. [http://dx.doi.org/10.1007/s00248-009-9633-6] [PMID: 20112014]

[7] Pedrazzani, R.; Alessandri, I.; Bontempi, E. Study of sulphatation of Candoglia marble by means of micro X-ray diffraction experiments. Appl. Phys. A-Mater, 2006, 83, 689-694. [http://dx.doi.org/10.1007/s00339-006-3539-7]

[8] Cappitelli, F.; Toniolo, L.; Sansonetti, A.; Gulotta, D.; Ranalli, G.; Zanardini, E.; Sorlini, C. Advantages of using microbial technology over traditional chemical technology in removal of black crusts from stone surfaces of historical monuments. Appl. Environ. Microbiol., 2007, 73(17), 5671-5675. [http://dx.doi.org/10.1128/AEM.00394-07] [PMID: 17601804]

[9] Gioventù, E.; Lorenzi, P.F.; Villa, F. Comparing the bioremoval of black crusts on colored artistic lithotypes of the Cathedral of Florence with chemical and laser treatment. Int. Biodeterior. Biodegradredation, 2011, 65, 832-839. [http://dx.doi.org/10.1016/j.ibiod.2011.06.002]

[10] Troiano, F.; Gulotta, D.; Balloi, A. Successful combination of chemical and biological treatments for the cleaning of stone artworks. Int. Biodeterior. Biodegradredation, 2013, 85, 294-304. [http://dx.doi.org/10.1016/j.ibiod.2013.08.011]

[11] Alfano, G.; Lustrato, G.; Belli, C. The bioremoval of nitrate and sulfate alterations on artistic stonework: the case-study of Matera Cathedral after six years from the treatment. Int. Biodeterior. Biodegradredation, 2011, 65, 1004-1011. [http://dx.doi.org/10.1016/j.ibiod.2011.07.010]

[12] Bosch-Roig, P.; Regidor-Ros, J.L.; Montes-Estelles, R. Biocleaning of nitrate alterations on wall paintings by Pseudomonas stutzeri. Int. Biodeterior. Biodegradredation, 2013, 84, 266-274.

[http://dx.doi.org/10.1016/j.ibiod.2012.09.009]

[13] Mukhopadhyay, R. Bacteria rescue fresco. Anal. Chem., 2005, 77, 457A-458A. [http://dx.doi.org/10.1021/ac053514v]

[14] Ranalli, G.; Alfano, G.; Belli, C.; Lustrato, G.; Colombini, M.P.; Bonaduce, I.; Zanardini, E.; Abbruscato, P.; Cappitelli, F.; Sorlini, C. Biotechnology applied to cultural heritage: biorestoration of frescoes using viable bacterial cells and enzymes. J. Appl. Microbiol., 2005, 98(1), 73-83.

[http://dx.doi.org/10.1111/j.1365-2672.2004.02429.x] [PMID: 15610419]

[15] Mazzoni, M.; Alisi, C.; Tasso, F. Laponite micro packs for the selective cleaning of multiple coherent deposits on wall paintings: The case study of Casina Farnese on the Palatine Hill (Rome-Italy). Int. Biodeterior. Biodegradation, 2014, 94, 1-11.

[http://dx.doi.org/10.1016/j.ibiod.2014.06.004]

[16] Daskalakis, M.I.; Magoulas, A.; Kotoulas, G.; Catsikis, I.; Bakolas, A.; Karageorgis, A.P.; Mavridou, A.; Doulia, D.; Rigas, F. Pseudomonas, Pantoea and Cupriavidus isolates induce calcium carbonate precipitation for biorestoration of ornamental stone. J. Appl. Microbiol., 2013, $115(2), 409-423$.

[http://dx.doi.org/10.1111/jam.12234] [PMID: 23621825]

[17] Sanmartín, P.; Cappitelli, F.; Mitchell, R. Current methods of graffiti removal: A review. Construct. Build. Mater., 2014, 71, 363-374. [http://dx.doi.org/10.1016/j.conbuildmat.2014.08.093]

[18] Troiano, F.; Vicini, S.; Gioventù, E. A methodology to select bacteria able to remove synthetic polymers. Polym. Degrad. Stabil., 2014, 107, 321-327.

[http://dx.doi.org/10.1016/j.polymdegradstab.2013.12.029]

[19] Giacomucci, L.; Toja, F.; Sanmartín, P.; Toniolo, L.; Prieto, B.; Villa, F.; Cappitelli, F. Degradation of nitrocellulose-based paint by Desulfovibrio desulfuricans ATCC 13541. Biodegradation, 2012, 23(5), 705-716. [http://dx.doi.org/10.1007/s10532-012-9546-9] [PMID: 22367465]

[20] Bosch-Roig, P.; Lustrato, G.; Zanardini, E.; Ranalli, G. Biocleaning of Cultural Heritage stone surfaces and frescoes: which delivery system can be the most appropriate? Ann. Microbiol., 2015, 65, 1227-1241. [http://dx.doi.org/10.1007/s13213-014-0938-4]

[21] Mapelli, F.; Marasco, R.; Balloi, A.; Rolli, E.; Cappitelli, F.; Daffonchio, D.; Borin, S. Mineral-microbe interactions: biotechnological potential of bioweathering. J. Biotechnol., 2012, 157(4), 473-481. [http://dx.doi.org/10.1016/j.jbiotec.2011.11.013] [PMID: 22138043]

[22] Vergès-Belmin, V. Towards a definition of common evaluation criteria for the cleaning of porous building materials: a review. Sci. Technol. 
Cult. Herit., 1996, 5, 69-83.

[23] Webster, A.; May, E. Bioremediation of weathered-building stone surfaces. Trends Biotechnol., 2006, 24(6), 255-260. [http://dx.doi.org/10.1016/j.tibtech.2006.04.005] [PMID: 16647149]

Received: June 15, 2015

Revised: June 25, 2015

Accepted: July 31, 2015

(C) Francesca Cappitelli; Licensee Bentham Open.

This is an open access article licensed under the terms of the Creative Commons Attribution-Non-Commercial 4.0 International Public License (CC BY-NC 4.0) (https://creativecommons.org/licenses/by-nc/4.0/legalcode), which permits unrestricted, non-commercial use, distribution and reproduction in any medium, provided the work is properly cited. 